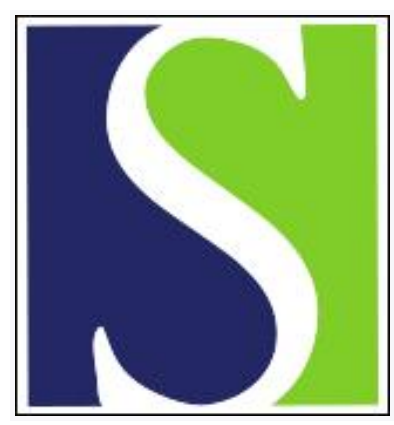

Scand J Work Environ Health 1996;22(6):438-443

https://doi.org/10.5271/sjweh.165

Issue date: Dec 1996

Transient increase in DNA strand breaks in car refinishing spray painters

by Fuchs J, Hengstler JG, Hummrich F, Oesch F

Key terms: alkaline elution; biomonitoring; DNA damage; human mononuclear blood cells; safety provision

This article in PubMed: www.ncbi.nlm.nih.gov/pubmed/9000311

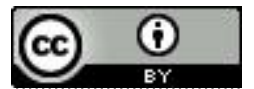




\title{
Transient increase in DNA strand breaks in car refinishing spray painters
}

\author{
by Jürgen Fuchs, PhD, Jan Georg Hengstler, MD, ${ }^{1}$ Frank Hummrich, ${ }^{1}$ Franz Oesch, PhD ${ }^{1}$
}

\begin{abstract}
Fuchs J, Hengstler JG, Hummrich F, Oesch F. Transient increase in DNA strand breaks in car refinishing spray painters. Scand J Work Environ Health 1996;22:438-43.

Objectives Genotoxic risk was evaluated for spray painters possibly exposed to polyester resins and acrylic enamel-based paints in automotive body repair shops.

Methods DNA (deoxyribonucleic acid) strand breaks and alkali-labile sites were measured in peripheral mononuclear blood cells ex vivo using the alkaline elution method. Samples of venous blood were taken on Monday after a free weekend and again on Friday from 38 male and 1 female spray painters and compared with the blood samples from 36 male and 3 female referents. The elution rate of each DNA sample was standardized by dividing it by the elution rate obtained from simultaneously sampled untreated Chinese hamster V79 cells. Results The spray painters showed a significantly $(\mathrm{P}<0.001)$ higher mean level of strand breaks and alkalilabile sites in the Friday samples [2.05 (SE 0.17)] compared with the Monday samples [1.38 (SE 0.07)]. The Monday results of the spray painters were not distinguishable from the referents' [1.41 (SE 0.10)]. The increase in DNA damage was numerically higher, but only weakly significant (use of masks, $\mathrm{P}<0.05$ ) or nonsignificant (use of spray booths), when fewer safety provisions were taken.

Conclusions A significant increase in DNA strand breaks and alkali-labile sites was found in spray painters after a week's work. However, DNA damage seems to be reversible. The use of modern safety equipment seems to affect DNA damage only marginally. There is an urgent need to identify the genotoxic chemicals in the occupational environment of spray painters and to develop corresponding satisfactory safety measures.
\end{abstract}

Key terms alkaline elution, biomonitoring, DNA damage, human mononuclear blood cells, safety provisions.

Workers at modern industrial or craftsman workplaces are often exposed to a plurality of chemicals. Especially car refinishing workers have such exposure. Spray painters are exposed to a variety of solvents and paint ingredients while spraying the different coats of paint or cleaning their tools. Elofsson et al (1) quantified up to 20 different solvents during personal sampling measurements for painters. The workers were often simultaneously exposed to 8 to 10 solvents. In addition, car refinishing workers are possibly exposed to chemicals used in the polyester or epoxy resins to level out the roughness of repaired metal parts. Exposure to chemicals during welding and soldering processes and to automotive exhaust and fuel components also has to be considered for workers in this group.

Three large cohort studies of cancer in painters were reviewed by IARC (2). These studies revealed an excess of all cancers in painters of about $20 \%$ above the national average. Lung cancers were found in painters about $40 \%$ more often than in the average population. The evidence that occupational exposure as a painter is carcinogenic was classified to be sufficient. In a study based on the New Zealand cancer register, Bethwaite et al (3) found a higher incidence of bladder tumors, kidney and other urothelial tumors, and multiple myeloma among painters. Risk for multiple myeloma was greater among car and spray painters than among general painters. Myslak et al (4) also observed a higher risk of bladder tumors among painters. Furthermore, there is evidence for an effect of the occupational exposure of spray painters on their offspring. Children of male spray painters were found to have a slightly but significantly lower mean height and weight at birth (5).

However, compared with other occupational groups, very little is known about the genotoxic, clastogenic, and mutagenic effect of the occupational exposure among spray painters. In a group of 117 painters, no significant increase in sister chromatid exchange frequency was found (6). In addition, in a group of Swedish paint industry workers, Haglund et al (7) did not find a significant increase in sister chromatid exchanges or chromosome aberrations. Results of a cytogenetic analysis carried out

Institute of Toxicology, University of Mainz, Mainz, Germany.

Reprint requests to: Dr J Fuchs, Institute of Toxicology, University of Mainz, Obere Zahlbacherstrasse 67, D-55131 Mainz, Germany. 
for humans exposed to epoxy resins are inconclusive. Suskov \& Sazonova (8) found a significant increase in chromosome aberrations in workers exposed to epoxy resins, while Mitelman et al (9) did not find any significant difference between exposed workers and referents.

In order to evaluate the genotoxic hazard for spray painters, we used the alkaline elution method to investigate the numbers of DNA (deoxyribonucleic acid) strand breaks and alkali-labile sites (in short: DNA strand breaks) in peripheral mononuclear blood cells of workers. The measurement of DNA strand breaks in human peripheral mononuclear blood cells has been shown to be a sensitive tool for monitoring the genotoxic effects of various occupational exposures (10-14). By analyzing genotoxic effects directly in workers, rather than measuring the concentration of possibly genotoxic chemicals in the air or in body fluids, also individual differences in susceptibility, for example, due to enzymatic polymorphisms, can be evaluated (15). Furthermore, modulation of the genotoxic effect of substances in the occupational environment by individual coexposures such as cigarette smoking can be observed (16).

\section{Subjects and methods}

\section{Description of subjects}

In this study 38 male and 1 female spray painters from 14 automotive body repair shops were included. The workers were employed in small to medium-size repair shops with 1 to about 20 workers occupied with car spray painting. The median age of the workers was 28 years with a range of 16 to 62 years. The workers had been occupied as spray painters for 0.5 to 48 years with a median of 11 years. Fifteen of the workers were nonsmokers, and one painter smoked only occasionally. The others consumed from 10 to 40 cigarettes per day on an average during at least the last three weeks with a median of 25 cigarettes per day (table 1 ).

Table 1. Demographic data and level of DNA strand breaks in mononuclear blood cells of the car refinishing spray painters ( $S L_{\text {Mon }}=$ level of DNA strand breaks on Monday, $\mathrm{SL}_{\mathrm{Fr}}=$ level of DNA strand breaks on Friday)

\begin{tabular}{|c|c|c|c|c|c|c|c|c|c|}
\hline \multirow{2}{*}{$\begin{array}{l}\text { Proband } \\
\text { number }\end{array}$} & \multirow{2}{*}{$\begin{array}{c}\text { Age } \\
\text { (years) }\end{array}$} & \multirow{2}{*}{$\begin{array}{c}\text { Cigarettes } \\
\text { per day }\end{array}$} & \multirow[t]{2}{*}{$S L_{\text {Mllon }}$} & \multirow[t]{2}{*}{$S L_{f r}$} & \multirow{2}{*}{\multicolumn{2}{|c|}{$\begin{array}{cc}\text { Lifetime } & \text { Daily spraying } \\
\text { occupation } & \text { time } \\
\text { (years) } & \text { (hours) }\end{array}$}} & \multicolumn{3}{|c|}{ Safety equipment } \\
\hline & & & & & & & $\begin{array}{c}\text { Charcoal } \\
\text { mask }\end{array}$ & $\begin{array}{l}\text { Dust } \\
\text { mask }\end{array}$ & $\begin{array}{l}\text { Spray } \\
\text { booth }\end{array}$ \\
\hline 1 & 36 & occasionally & 1.595 & 2.619 & 16 & .. & no & no & no \\
\hline 2 & 31 & 40 & 1.405 & 2.071 & 16 &.. & no & no & no \\
\hline 3 & 26 & 20 & 1.571 & 3.286 & 9 & 2.5 & yes & yes & yes \\
\hline 4 & 23 & - & 1.357 & 2.309 & 5 & 2 & no & yes & yes \\
\hline 5 & 27 & - & 1.554 & 2.789 & 12 & 4 & yes & yes & no \\
\hline 6 & 18 & - & 1.234 & 1.823 & 1 & 4 & yes & yes & no \\
\hline 7 & 18 & - & 1.091 & 1.337 & 2 & 4 & yes & yes & no \\
\hline 8 & 62 & 40 & 0.629 & 1.023 & 48 & 4 & yes & yes & no \\
\hline 9 & 43 & 40 & 1.401 & 1.617 & 10 &.. & yes & no & yes \\
\hline 10 & 36 & - & 1.136 & 1.579 & 21 &.. & yes & no & yes \\
\hline $11^{\mathrm{a}}$ & 16 & - & 1.107 & 1.313 & 0.5 & .. & yes & no & yes \\
\hline 12 & 44 & 40 & 1.037 & 0.967 & 25 & .. & yes & no & yes \\
\hline 13 & 41 & 40 & 1.716 & 1.509 & 24 & .. & yes & yes & yes \\
\hline 14 & 27 & - & 2.360 & 2.515 & 11 & 1.75 & yes & yes & yes \\
\hline 15 & 39 & 20 & 2.036 & 2.917 & 24 & 8 & yes & yes & yes \\
\hline 16 & 39 & 30 & 1.308 & 2.289 & 24 & 1.75 & yes & yes & yes \\
\hline 17 & 40 & - & 1.814 & 2.054 & 25 & 1.75 & yes & yes & yes \\
\hline 18 & 34 & 25 & 0.984 & 1.295 & 20 & 1.75 & yes & yes & yes \\
\hline 19 & 35 & 25 & 0.938 & 1.054 & 20 & 1.75 & yes & yes & yes \\
\hline 20 & 28 & - & 1.000 & 1.031 & 12 & 1.75 & yes & yes & yes \\
\hline 21 & 26 & 20 & 1.545 & 1.652 & 10 & 1.75 & yes & yes & yes \\
\hline 22 & 25 & - & 0.969 & 0.893 & 9 & 1.75 & yes & yes & yes \\
\hline 23 & 24 & - & 0.803 & 0.758 & 7 & 1.75 & yes & yes & yes \\
\hline 24 & 22 & 20 & 0.969 & 1.803 & 5 & 1.75 & yes & yes & yes \\
\hline 25 & 19 & 20 & 2.423 & 3.026 & 3 & 1.75 & yes & yes & yes \\
\hline 26 & 18 & 20 & 1.577 & 1.577 & 2 & 1.75 & yes & yes & yes \\
\hline 27 & 18 & 15 & 0.653 & 0.936 & 1 & 1.75 & yes & yes & yes \\
\hline 28 & 18 & - & 0.820 & 1.307 & 1 & 1.75 & yes & yes & yes \\
\hline $\begin{array}{l}20 \\
29\end{array}$ & 16 & 15 & 1.666 & 4.357 & 1 & 1.75 & yes & yes & yes \\
\hline 30 & 56 & - & 1.952 & 5.786 & 42 & 1.75 & yes & yes & yes \\
\hline 31 & 57 & 25 & 1.643 & 2.380 & 30 & .. & no & no & yes \\
\hline 32 & 53 & - & 1.524 & 3.857 & 25 & 2 & yes & no & yes \\
\hline 33 & 27 & 25 & 2.100 & 2.980 & 10 &.. & .. & yes &.. \\
\hline 34 & 28 & - & 1.500 & 1.460 & 1 & .. & .. & yes &.. \\
\hline 35 & 19 & 10 & 1.720 & 2.540 & 3 &.. & no & no & no \\
\hline 36 & 25 & 10 & 1.040 & 2.180 & 7 & .. & .. & yes & .. \\
\hline 37 & 51 & 25 & 1.012 & 2.096 & 20 & .. & no & no & no \\
\hline 38 & 41 & 25 & 1.881 & 2.155 & 30 & 2.5 & yes & yes & yes \\
\hline 39 & 38 & 15 & 0.600 & 0.820 & 30 & 2.5 & yes & yes & yes \\
\hline
\end{tabular}

a Female. 
The painters were occupied for 8 to $9 \mathrm{~h}$ a day. The median actual daily spray painting time was $1.75 \mathrm{~h}$ with a range from 1.5 to $8 \mathrm{~h}$. Eighty-four percent of the workers were occupied with spray painting between 1.5 to $2.5 \mathrm{~h}$ a day (table 1 ). Only one worker spray-painted exclusively ( $8 \mathrm{~h}$ a day). In all the repair shops, paints applied by compressed air spraying almost exclusively had an acrylic enamel base. Only on some rare occasions had water-based paints been used. No spray painter was occupied with motor repair or body sheet welding. None of the painters showed or reported any complaints related to the workplace.

Ten of the 14 repair shops employing 31 of the painters possessed a special spray booth. The booths were supplied with fans and inlet and exhaust filters. Whole-body overalls and masks with a breathing air supply from the outside were available and used most of the time, as reported by the workers. The booths were used to paint whole automobile bodies. Smaller parts, such as single fenders or doors, were primarily painted in the main workhall. When not working in the spray booths, 30 of 36 workers used masks with charcoal filters during spraying. Masks with dust filters were used by 26 of 31 workers during grinding or sanding.

The referents ( 36 men, 3 women) were healthy office employees and students, who did not use drugs, had no known occupational exposure to chemicals or ionizing radiation, and lived in the same area as the investigated workers, an industrial town with about 200000 inhabitants. The median age of the referents was 26 (range $20-54$ ) years. Twenty-five of the referents were nonsmokers, one smoked occasionally, and 13 consumed 5 to 30 cigarettes per day on an average during at least the last three weeks with a median of 15 cigarettes per day. One-half of the blood samples of the referents were taken on a Monday and the other half on a Friday.

\section{Alkaline elution}

From each individual $20 \mathrm{ml}$ of heparinized venous blood was taken. All the blood samples were transported on ice and processed within $4 \mathrm{~h}$. Mononuclear blood cells were isolated by metrizoate-Ficoll centrifugation according to Boyum (17). Isolated mononuclear blood cells were frozen using a freezing protocol from Cryoson, Schoellgrippen, Germany. The cells were stored at $-196^{\circ} \mathrm{C}$ until use.

The unfractionated alkaline elution method was employed as described by Fuchs et al (15). In brief, a suspension of 1.5 million mononuclear blood cells in $1 \mathrm{ml}$ of ice-cold phosphate-buffered saline was poured onto a polycarbonate filter (Nucleopore, Tübingen, Germany; $25 \mathrm{~mm}$ diameter, $2 \mu \mathrm{m}$ pore size). Cells were lysed for $60 \mathrm{~min}$ with $3 \mathrm{ml}$ of a solution of $10 \mathrm{mM}$ ethylenediaminetetraacetic acid (EDTA), $0.5 \%$ Triton X-100, and $2 \mathrm{M}$ sodium chloride, adjusted to $\mathrm{pH} 10$ by sodium hydroxide.
The cells were then washed with $4.5 \mathrm{ml}$ of $10 \mathrm{mM}$ EDTA $\left(\mathrm{pH} \mathrm{10)}\right.$ for $90 \mathrm{~min}$. The elution was performed at $4^{\circ} \mathrm{C}$ in the dark with a flow rate of $1.5 \mathrm{ml} \cdot \mathrm{h}^{-1}$ using a $5 \mathrm{M}$ sodium chloride, $2 \mathrm{mM}$ EDTA solution adjusted to $\mathrm{pH} 12.6$ with sodium hydroxide. One fraction was collected over a period of $10 \mathrm{~h}$. The filters were sonicated in $15 \mathrm{ml}$ of elution buffer for $2 \times 15 \mathrm{~min}$ to remove retained DNA. Quantification of the DNA was performed as described recently (18). For standardization, DNA of untreated Chinese hamster V79 cells was eluted simultaneously in every run on separate filters. V79 cells were cultured as described (18). DNA concentrations of the eluted fractions and of the filter fractions were determined in triplicate. The elution rate was calculated as $\left(\log _{10} \mathrm{R}\right) / 10 \mathrm{~h}$, in which $\mathrm{R}$ represents the fraction of DNA remaining on the filter after $10 \mathrm{~h}$ of elution. For standardization the level of DNA strand breaks was expressed as the ratio of the elution rate of test cell DNA to the elution rate of V79 DNA. DNA of the peripheral mononuclear blood cells, as well as DNA of the V79 cells, was eluted on three separate filters each, and the mean values of these three elution runs were calculated.

\section{Statistical evaluations}

The two-sided U-test according to Wilcoxon, Mann, and Whitney for unpaired data sets was used to compare the DNA strand break levels of the painters and the referents. The Wilcoxon signed rank test for paired data was applied to evaluate the statistical significance of differences between the individual strand-break levels of the same persons on Mondays and Fridays. Mean values and standard errors (SE) and, if indicated, median values and the range are presented.

\section{Results}

On Monday the 39 spray painters showed a mean level of DNA strand breaks of 1.38 (SE 0.07) (figure 1). For the cigarette smokers of this group a mean level of strand breaks of 1.39 (SE 0.10) and for the nonsmokers of 1.35 (SE 0.11) was obtained. For the reference group a mean level of DNA strand breaks of 1.41 (SE 0.10) [smokers: 1.39 (SE) 0.15, nonsmokers: 1.43 (SE 0.13)] was calculated. No statistically significant difference was observed for the level of strand breaks between the referents' and spray painters' Monday blood samples. However, in the Friday sampling, the mean level of the DNA strand breaks in the peripheral mononuclear blood cells of the spray painters was increased by $48 \%$ to 2.05 (SE 0.17 ) [nonsmokers: 2.05 (SE 0.34); smokers: 2.02 (SE 0.13)], which was significantly higher $(\mathrm{P}<0.005)$ than what was 
observed for the referents. Thirty-three painters showed an increase in their level of strand breaks from Monday to Friday. For five of the painters a marginal decrease was observed, and for one there was no change in the strand break level on Friday. With the use of the Wilcoxon rank test for paired data, the increase of the strand break level during the week was shown to be statistically highly significant $(\mathrm{P}<0.001)$.

No dependency of the increase in DNA strand breaks on the daily spraying time was observed. Workers employed in repair shops with spray booths showed a mean increase in DNA strand breaks of 0.65 (SE 0.16) during the week of occupational exposure, while for those workers from repair shops without spray booths a mean increase of 0.76 (SE 0.12) was calculated. The difference in the increase in DNA damage between the two groups was not statistically significant. Spray painters who reported using masks with charcoal filters showed an increase of 0.63 (SE 0.18) in the mean DNA strand break level from the measurement on Monday to that on Friday. For workers not using charcoal filter masks, a mean increase of 0.86 (SE 0.07) was obtained. The difference in the increase in DNA damage between both groups was weakly significant $(\mathrm{P}<0.05)$.

The repair shops were classified into three categories according to the subjective estimation by one of the authors (FH), who based his assessment on the smell in the workhalls. Six shops with 23 workers were classified into category I (no or only minor smell). Eight workers were employed in three shops where smell was moderately strong (category II), and eight spray painters worked in five shops with an intense solvent smell (category III). Workers employed in companies of category I showed a mean increase in DNA strand breaks of 0.63 (SE 0.20), while for the other workers a mean increase in DNA strand breaks of 0.65 (SE 0.16) (category II) and of 0.81 (SE 0.26) (category III) was obtained. However, no significant dependency was found between the increase in DNA strand breaks and this classification.

Neither the age of the workers nor the period of occupation in the current job significantly correlated with the levels of DNA strand breaks or the alteration of the strand break level during the week.

\section{Discussion}

During the week of occupational exposure, a significant increase in DNA strand breaks was observed in the group of spray painters. On Monday after a free weekend no differences in the mean strand break levels of the painters and a reference group were observed. The increased level of DNA-strand breaks caused by the occupational

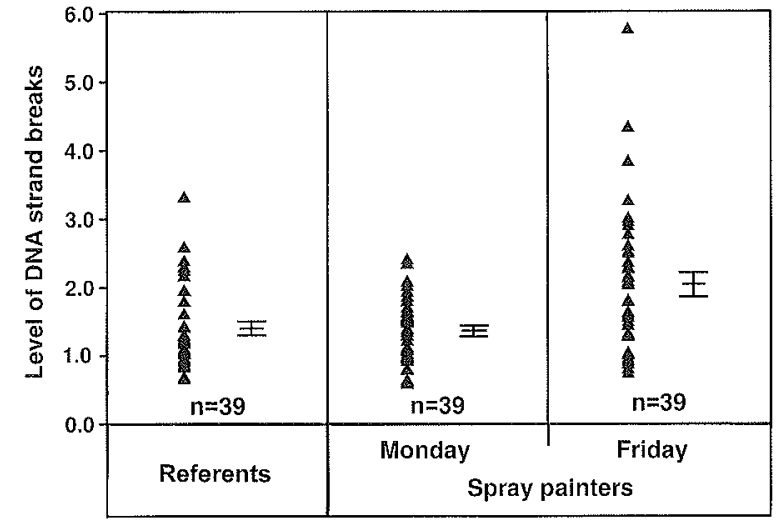

Figure 1. Individual levels of DNA strand breaks and alkali-labile sites in peripheral mononuclear blood cells of the spray painters and the referents. Blood samples were taken from the spray painters on Mondays and Fridays. The means and standard errors are also shown. The mean level of strand breaks in the blood samples of the spray painters taken on Friday was significantly different $(P<0.001)$ from the mean level of strand breaks found in the blood samples taken on Monday and also $(P<0.005)$ from the level of strand breaks obtained for the referents.

exposure was therefore persistent only for a short period. It appears that the DNA damaging agents were detoxified and the induced DNA strand breaks were repaired within two and a half days. Spray painters are possibly exposed to a variety of genotoxic chemicals. The acrylic enamel paints used in the investigated shops were mixed with hardener containing isocyanates such as hexamethylene and toluene diisocyanate. To dilute the paints prior to spraying, various mixtures of xylol, acetone, toluene, aliphatic esters, and acetates were used. But also benzene was found in the workplace environment of the spray painters (19). The polyester-based body fillers and fiberglass resins contained styrene in an amount of up to $35 \%$. The hardeners contained benzoylperoxide. Fiberglass patchwork was very seldom applied.

In a comparable earlier study we investigated DNA strand breaks in peripheral mononuclear blood cells of other painters using brushes and rollers but no spray pistols for painting (16). According to the results of our study, a higher level of DNA strand breaks was found on Friday than on Monday but in the nonspraying painters the level of DNA strand breaks was still increased on Monday compared with that of the referents. Therefore, the DNA damage in the nonspraying painters was repaired or the genotoxic agents were detoxified less efficiently than in the spray painters. One difference in the work conditions of the two groups may have been the amount of organic solvent vapor the painters were exposed to. The concentration of solvent vapor was considered to be substantially higher for the spray painters.

The increase in DNA strand breaks in the spray painters was not clearly associated with any of the exposure- 
related parameters we investigated. Neither the factual daily spraying time nor the number of years employed as a spray painter had an effect on the observed increase in DNA damage. The quality of the protective equipment had only a weak or nonsignificant impact on the increase of the DNA damage during the week. Workers in companies with modern spray booths showed only a tentatively smaller increase in DNA strand breaks than workers in companies with poor or no protective equipment. The use of charcoal filter masks had a weakly significant protective effect. One explanation could be that the workers did not use the safety equipment as extensively as reported or that the genotoxic substances occurring during spray painting were not sufficiently retained on the filters. Elofsson et al (1) showed that, for car spray painters, the amount of solvents incorporated into the body during color mixing, degreasing, and cleaning is similar to the amount of solvents incorporated during spray painting with modern safety equipment. Therefore even workers with modern protective equipment available during spray painting have a basic level of incorporated solvents or paint ingredients. It is also possible that the genotoxic effects were caused by enzymatically activated metabolites of the originally incorporated chemicals. Enzymatic processes can be rate limited. Incorporated chemicals will then be activated dose-dependently only up to a certain, possibly low concentration. An extended amount of incorporated chemicals will not be processed by the enzymes and therefore may not result in an increased genotoxic effect. To validate these assumptions, measurements of the internal burden of selected solvents or paint ingredients are needed. Furthermore, the genotoxic effect may not be totally or mainly caused by the paints or the paint components, instead by other chemicals in the occupational environment of the car refinishing workers. For example, the dust ingredients produced during the sanding of body filler enamel, fiberglass resins or the primer layer may play an important role.

Contrary to investigations of other occupational groups $(15,16,20)$, no effect of the coexposure of cigarette smoking on the genotoxicity of the occupational exposure could be detected in the group of spray painters. Smoking and nonsmoking spray painters had nearly the same mean increase in DNA strand breaks during the week.

Although the DNA damage found in the spray painters was not persistent and was not detectable after a free weekend, the accumulation of misrepaired DNA sites could imply a substantial risk for the workers. Therefore, there is an urgent need to identify the chemicals and the mechanisms responsible for the increase in DNA damage in spray painters. Furthermore efforts should be undertaken to improve both the protective steps used in automotive body repair shops during spray painting and the other phases of the work.

\section{Acknowledgments}

This study contains parts of F Hummrich's doctoral dissertation.

\section{References}

1. Elofsson S-A, Gamberale F, Hindmarsh T, Iregren A, Isaksson A, Johnsson I, et al. Exposure to organic solvents: a crosssectional epidemiologic investigation on occupationally ex posed car and industrial spray painters with special reference to the nervous system. Scand J Work Environ Health 1980;6: $239-73$.

2. International Agency for Research on Cancer (IARC). Some organic solvents, resin monomers and related compounds, pigments and occupational exposures in the paint manufacture and painting. Lyon: IARC, 1989. IARC Monographs on the evaluation of carcinogenic risk to humans, vol 47.

3. Bethwaite PB, Pearse N, Fraser J. Cancer risk in painters: study based on the New Zealand Cancer Registry. Br J Ind Med 1990;47:742-6.

4. Myslak ZW, Bolt HM, Brockmann W. Tumors of the urinary bladder in painters: a case-control study. Am J Ind Med 1991; $19: 705-13$

5. Höglund GV, Iselius EL, Knave BG. Children of male spray painters: weight and length at birth. Br J Ind Med 1992;49: $249-53$.

6. Kelsey KT, Wiencke JK, Little FF, Baker EL, Little JB. Effects of cigarette smoking and solvent exposure on sister chromatid exchange frequency in painters. Environ Mol Mutagen 1988;11:389-99.

7. Haghund U, Lundberg I, Zech L. Chromosome aberrations and sister chromatid exchanges in Swedish paint industry workers. Scand J Work Environ Health 1980;6:291-98

8. Suskov II, Sazonova LA. Cytogenetic effects of epoxy, phenolformaldehyde and polyvinylchloride resins in man. Mutat Res 1982;104:137-40.

9. Mitelman F, Fregert S, Hedner K, Hillbertz-Nilsson K. Occupational exposure to epoxy resins has no cytogenetic effect. Mutat Res 1980;77:345-8.

10. Walles SA, Norppa H, Osterman-Golkar S, Mäki-Paakkanen J. Single strand breaks in DNA of peripheral lymphocytes of styrene-exposed workers. IARC Sci Publ 1988;89:223-6.

11. Popp W, Vahrenholz C, Yaman S, Müller C, Müller G, Schmieding $W$, et al. Investigation of the frequency of DNA strand breakage and cross-linking and of sister chromatid exchange frequency in lymphocytes of female workers exposed to benzene and toluene. Carcinogenesis 1992;13:57-61.

12. Walles SA, Edling C, Anundi H, Johanson G. Exposure de pendent increase in DNA single strand breaks in leucocytes from workers exposed to low concentrations of styrene. $\mathrm{Br} \mathrm{J}$ Ind Med 1993;50:570-4.

13. Fuchs J, Hengstler JG, Jung D, Hiltl G, Konietzko J, Oesch F DNA damage in nurses handling antineoplastic agents. Mutat Res 1995;342:17-23.

14. Fuchs J, Burg J, Hengstler JG, Bolm-Audorff U, Oesch F. DNA damage in mononuclear blood cells of metal workers exposed to $\mathrm{N}$-nitrosodiethanolamine in synthetic cutting fluids. Mutat Res 1995;342;95-102.

15. Fuchs J, Wullenweber U, Hengstler JG, Bienfait HG, Hiltl G, Oesch F. Genotoxic risk for humans due to a working place 
exposure to ethylene oxide: remarkable individual differences in susceptibility. Arch Toxicol 1994;68:343-8.

16. Oesch F, Hengstler JG, Fuchs J. Cigarette smoking protects mononuclear blood cells of carcinogen exposed workers from additional work-exposure-induced DNA single strand breaks. Mutat Res 1994;321:175-85.

17. Boyum A. Separation of white blood cells. Nature [Lond] 1964;204:793.

18. Hengstler JG, Fuchs J, Oesch F. DNA strand breaks and DNA cross-links in peripheral mononuclear blood cells of human ovarian cancer patients during chemotherapy with cyclophosphamide/carboplatin. Cancer Res 1992;52:5622 -6.

19. Jayjock MA, Levin L. Health hazards in a small automotive body repair shop. Am Occup Hyg 1984;28:19-29.

20. Oesch F, Fuchs J, Vaupel J, Hengstler JG. DNA single strand break analysis in mononuclear blood cells of petrol pump attendants. Int Arch Occup Environ Health 1995;67:35-9.

Received for publication: 14 November 1995 